\title{
Preserving an obscure bird: achievements and future challenges of Corncrake (Crex crex Linnaeus, 1758) conservation in Hungary
}

\author{
István Szentirmai $^{1 *}$, Sándor András Boldogh ${ }^{2,3}$, Károly NaGY $^{4}$, \\ Béla HABARICS ${ }^{5}$ \& Tibor SzÉP 6
}

Received: November 7, 2016-Accepted: November 22, 2016

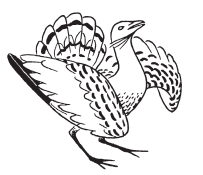

István Szentirmai, Sándor András Boldogh, Károly Nagy, Béla Habarics \& Tibor Szép 2016. Preserving an obscure bird: achievements and future challenges of Corncrake (Crex crex Linnaeus, 1758) conservation in Hungary. - Ornis Hungarica 24(2): 1-17. many NatuRa 2000 sites. Despite its Least concern global conservation status, it receives much attention and was elected as "Bird of the Year" by MME BirdLife Hungary in 2016. In this paper, we estimate its population trends and analyse the suitability of the protected area system and agri-environment schemes for the species. We compiled information on major threatening factors and conservation measures applied for the species. We reviewed international publications on the ecology and conservation management of the species to extract information for practical conservation. We estimated that 500-2000 pairs of Corncrakes breed in Hungary. Although their breeding sites are well covered by protected areas, NATURA 2000 sites (42\%) and High Nature Value Areas (67\%), their population has declined by $55 \%$ over the last 20 years. We found that most of the major threatening factors are addressed by conservation management, and appropriate measures are applied in most cases. Recent research findings and recommendations by the BirdLife International Corncrake Conservation Team suggest that mowing of grasslands around nesting places should be delayed until 1-15 August either in the entire field or at least on 2 hectares around nests. Prescriptions of agri-environment schemes should also be adjusted to the above requirements and more farmers should be encouraged to enrol in Corncrake conservation programmes. We strongly suggest that more emphasis should be devoted to combat important threats for the most important breeding sites such as aridification and flooding.

Keywords: population trend, agri-environment scheme, conservation measures, delayed mowing, refuge stripe

Összefoglalás A haris fokozottan védett faj, és jelölőfaja számos NATURA 2000 területnek Magyarországon. Annak ellenére, hogy globálisan nem veszélyeztetett, hazánkban mégis jelentős figyelmet kap, és a Magyar Madártani és Természetvédelmi Egyesület programjában is elnyerte a 2016-os „év madara” címet. Jelen tanulmányban megbecsültük jelenlegi állománynagyságát, és elemeztük annak változásait, valamint vizsgáltuk, hogy mennyire megfelelő a védett és NATURA 2000 területek, valamint a Magas Természeti Értékủ Területek (MTÉT) elhelyezkedése a haris számára. Összegyüjtöttük a faj számára legjelentősebb veszélyeztető tényezőket, és az érdekében alkalmazott természetvédelmi intézkedéseket. Felkutattuk a nemzetközi szakirodalmat, és kigyüjtöttük azokat az ökológiai és természetvédelmi biológiai információkat, melyek segíthetik a faj gyakorlati védelmét. Eredményeink szerint hazánkban 500-2000 pár haris költ évente. Bár a védett, NATURA 2000 (42\%) és MTÉT (67\%) területek nagy arányban fedik le a haris költőhelyeit, állománya mégis 55\%-kal csökkent az elmúlt 20 év során. A természetvédelmi intézkedések reagálnak a faj legfőbb veszélyeztető tényezőire, és az alkalmazott kezelések többsége is megfelelö. A legfrissebb kutatások és a BirdLife International Harisvédelmi Csoportjának ajánlása szerint a fészkek körüli kaszálást augusztus 1-15-ig szükséges elhalasztani, vagy az egész gyepterületen, vagy legalább 2 hektáron. Az agrár-környezetgazdálkodási programok elöírásait is a fentiekhez kell igazítani, és kívánatos volna minél több gazdát ösztönözni a programokban való részvételre. Kiemelten szükséges, hogy a természetvédelem olyan veszélyeztető tényezőkkel is foglalkozzon, mint például a legfontosabb élőhelyeket érintő szárazodás és az elöntések általi károkozás. 


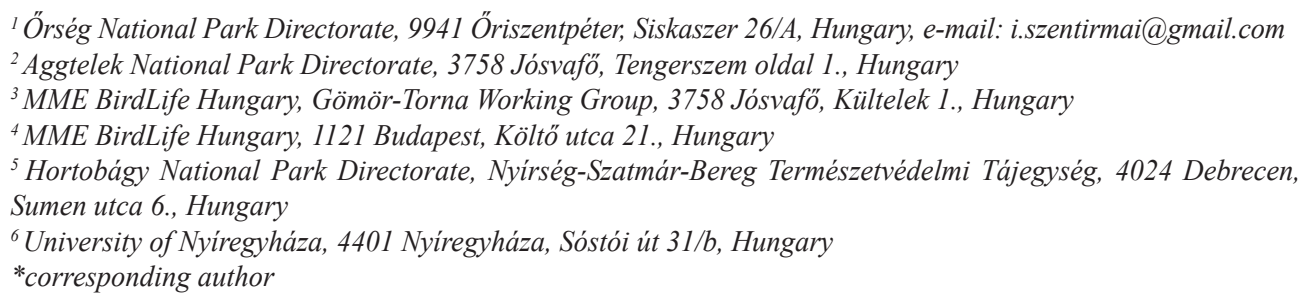

\section{Introduction}

The Corncrake (Crex crex) deserves special attention from ornithologists and conservationists for several reasons. It was elected as "Bird of The Year" in 2016 in the programme of the MME BirdLife Hungary, as it received more votes than the Quail (Coturnix coturnix) or the Eurasian Stone-curlew (Burhinus oedicnemus). In addition, Corncrake has a controversial conservation status, being a strictly protected species in Hungary (Ministry of Environment Decree No. 13/2001) and a Least Concern species in the Red List of IUCN (BirdLife International 2015). Furthermore, a decade has passed since the last comprehensive summary on the conservation biology of the Corncrake was published (Koffijberg \& Schäffer 2006), and a considerable amount of experience in practical conservation has been accumulated by now (see for example the special issue of Vogelwelt 136).

On the one hand, Corncrake is a priority species in Hungarian nature conservation, being strictly protected by law and a qualifying species of several Special Protection Areas (SPA) of the NATURA 2000 network. On the other hand, IUCN has recently downgraded the Corncrake to the Least Concern category on its Red List, mainly due to emerging information on large (1.515-2.740 million pairs) and stable Eastern European and Russian populations (BirdLife International 2015). Although this assessment was mainly based on expert opinion, a recent study, using species distribution modelling supported its outcome (Fourcade et al. 2013). These results may undermine the importance of conservation actions in Western and Central Europe from a global perspective. In spite of the IUCN assessment, some authors argue that our European populations still deserve attention and conservation efforts. Koffijberg et al. (2016) points out that Western and Southern European populations are still declining. In addition, agricultural intensification in the western part and land abandonment in the eastern part of the species' range is still ongoing and both processes may cause further habitat loss in the future. Authors also point to the uncertainties of population estimates from large populations (e.g. Russia), which make trends and future prospects difficult to assess. Another aspect of global Corncrake protection is the relationships and connections between distinct populations. A recent study found very low genetic structure and high genetic diversity across European populations, indicating that there may be intensive gene flow between populations (Fourcade et al. 2016). The authors argue that dispersion from eastern populations may be an important means of maintaining the declining populations in the West. Therefore, we believe that the Hungarian Corncrake population is worth the efforts of nature conservation and that its management should be further developed. 
Current knowledge on the biology and threatening factors of Corncrake were summarised by researchers by the early 2000s (Green et al. 1997, Schäffer \& Koffijberg 2004), and a European conservation action plan was released in 2006 (Koffijberg \& Schäffer 2006). Although these documents provided a solid basis for practical conservation, several studies have been published on the species and a large amount of experience has been gathered in conservation management since the time of their publication (see papers in the special issue of Vogelwelt 136).

Opportunities for Corncrake conservation have changed considerably in Hungary over the last decade. The NATURA 2000 network of the European Union was designated and incorporated into national legislation, including several SPAs declared for the protection of the species (Government Decree No. 275/2004). Within the framework of agri-environment schemes, High Nature Value Areas (HNVA) were also established and some programmes targeted the Corncrake as well (Rural Development Programme 2015-2020). From 2003 onwards, the number and total area of HNVA have been gradually increasing and their prescriptions improving.

In this paper, we attempt to evaluate the conservation status and future prospects of Corncrakes after two decades of extensive conservation efforts in Hungary by (i) estimating population trends, (ii) analysing the suitability of the protected area system and agri-environment schemes for the species and (iii) compiling information on major threatening factors. We collected and evaluated conservation measures applied for the species by conservation managers. We reviewed international research papers published on the ecology and conservation management of the species over the last 10 years to extract information that can help improving our practices in Hungary.

\section{Materials and methods}

\section{Population trends}

The Corncrake was a common bird in Hungary previously (Chernel 1899), but it became rare by the 1970s and 1980s (Szép 1991, Horváth 1998). Based on data from the Common Bird Monitoring (MMM) of Hungary during 1999-2012 (Szép et al. 2012), the Corncrake is a rare breeding species in Hungary with a mean frequency of 2.6\% (SE: 0.6). Between 167 and 1020 Corncrakes were recorded annually during 2007-2015, thus the size of the breeding population may currently be estimated at 500-2000 breeding pairs (MME BirdLife Hungary 2016). The majority of the population breeds in the northern and north-eastern part of the country, where the four most important regions are (i) Aggtelek National Park and its surroundings, (ii) small river valleys in the Zemplén Mountains, (iii) the floodplain of Tisza and Bodrog Rivers and (iv) Szatmár-Bereg (Wettstein 1999, Boldogh \& Szentgyörgyi 2003, Wettstein \& Szép 2003, Boldogh et al. 2009) (Figure 1).

For proper monitoring of population trends, specific schemes such as the Monitoring of Rare and Colonial Birds (RTM) (Szép \& Waliczky 1993) can provide data from populations that breed in specific regions. During the field surveys, international guidelines and methods 


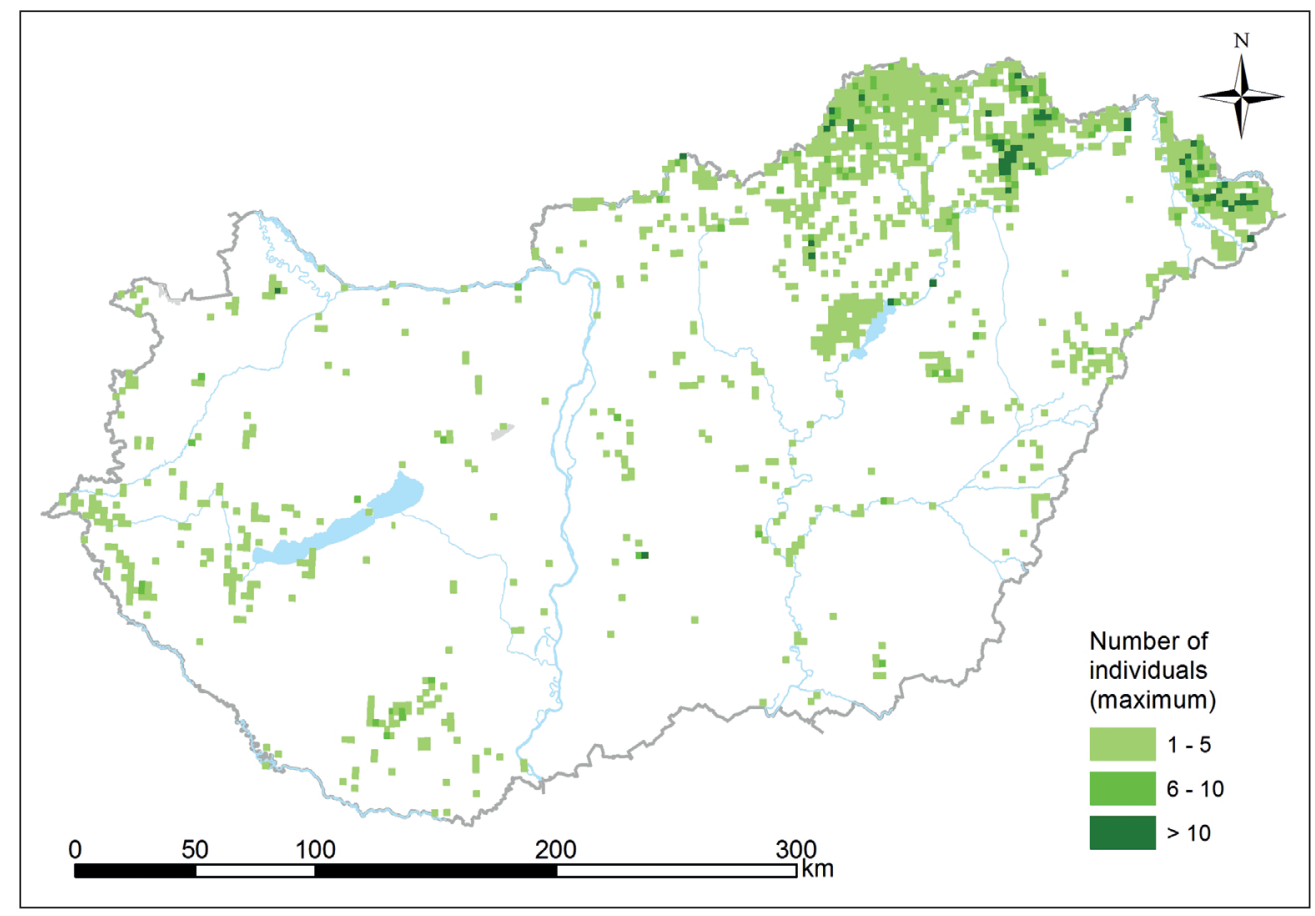

Figure 1. Distribution of Corncrakes in Hungary in 1997-2016

1. ábra A haris elterjedése Magyarországon 1997-2016

were followed (Schäffer \& Mammen 2003). The study areas are described elsewhere (see Boldogh et al. 2016a for details). To estimate long term population trends, we used data from Szatmár-Bereg and Aggtelek, two of the most important breeding sites in Hungary, between 1997 and 2016.

Annual population trends were calculated using TRIM software (Pannekoek \& van Strien 2001), which allows for missing counts in the time series and produces unbiased yearly indices and standard errors using Poisson regression (log-linear models; McCullagh \& Nelder, 1989). TRIM is used frequently in the case of national common bird monitoring schemes in Europe (Gregory et al. 2008). In the two studied populations, we used annual counts within the $2.5 \times 2.5 \mathrm{~km}$ UTM squares for trend analysis. In the case of the population of "Szatmár-Bereg", 141 idividual $2.5 \times 2.5 \mathrm{~km}$ UTM squares were surveyed, of which 12 did not have any positive observation of Corncrake. For the population of "Aggtelek", 167 UTM were surveyed, of which 21 did not have any positive observation.

For the trend modelling, we used the basic "Time Effect" model of the TRIM (expecting effects for each site and year) (Pannekoek \& van Strien 2001). Wald-test implemented in the TRIM was used to test similarity in the annual changes of the population indices of the two studied populations. Missing counts of particular sites were estimated ('imputed') from changes in all other sites (Pannekoek \& van Strien 2001). The TRIM produced imputed yearly indices with its $95 \%$ confidence intervals. The first year of the survey (breeding season: 1997) was the base year with a value of $100 \%$ and all other indices were calculated 
relative to this reference point. In addition, serial correlation was taken into account. The estimated slopes of the population trend (mean annual change based on multiplicative slope of imputed data with $95 \%$ confidence intervals, TRIM) reflect average percentage change per year. The overall slope estimate in TRIM software is converted into discrete categories (trend classification, van Strien et al. 2001). The category depends on the overall slope as well as on its $95 \%$ confidence interval. When the trend was not significant and the confidence intervals were sufficiently small, the species was classified as a stable population.

\section{Conservation status}

We used the database of MME BirdLife Hungary to investigate the coverage of Corncrake breeding sites by nationally protected areas and NATURA 2000 sites. Since the distribution data of Corncrake is stored on a $2.5 \times 2.5 \mathrm{~km}$ grid basis, we overlapped squares occupied by Corncrakes with the area of protected areas and NATURA 2000 sites and then calculated the percentage of area where they intersect. Then we calculated the percentage of the breeding populations that is recorded from UTM squares overlapping with protected or NATURA 2000 areas. We used ArcMap 10.2.1 GIS software for all spatial analyses. We studied agri-environment schemes and analysed whether they have relevant prescriptions for Corncrakes. Then we calculated the overlap between areas involved in agri-environment schemes with relevant prescriptions and the distribution area of the Corncrake the same way as described above for protected areas.

\section{Questionnaire survey}

To collect data on threatening factors to Corncrake and conservation measures that are applied for the species, we conducted a questionnaire survey among the experts of national park directorates. Corncrake experts were asked to list the most important current threats by regional breeding sites. They were asked to provide information on the importance and extent of each threat within each breeding site. Importance was categorised as high, medium and low, depending on the supposed severity on the performance of the population. Extent was defined as the percentage of area affected by the threat within the breeding site. In addition, experts were also asked to list those conservation measures that are applied to secure the persistence of Corncrake populations for each breeding site and indicate the percentage of the breeding population to which the measure is applied.

Altogether, we received data from 10 national park directorates, from 34 breeding sites. These breeding sites represented the Hungarian Corncrake population well enough, because only some minor populations were missed out due to the lack of regular monitoring and conservation management. From questionnaires, we calculated the number and percentage of breeding sites for each threatening factor, where it was found to be of either high, medium or low importance. Similarly, we calculated the number and percentage of breeding sites for each conservation measure, where it was applied, and the mean of the percentage of populations per breeding site to which it was applied. Note that more than one threatening factor may be in effect and more than one conservation measure can be applied within a single breeding site. 


\section{Results}

\section{Population trends}

The trend analysis showed that the size of the two studied breeding populations was similar and varied in a similar range during the studied period of 1997-2016 ("Aggtelek": 15-260 pairs, "Szatmár-Bereg": 53-286 pairs, TRIM). The population indices of the two breeding populations showed large annual fluctuation, but varied significantly differently (Wald-test: 342.33, $d f=19, P<0.001$, TRIM) (Figure 2). The breeding population of "Szatmár-Bereg" showed a steep population decline (mean annual change: $-9.9 \%$ (minimum: $-11.3 \%$, maximum: $-8.5 \%, P<0.01$, TRIM), whereas the population of "Aggtelek" had a large annual fluctuation with a stable trend over the studied period (mean annual change: $-0.7 \%$, minimum: $-1.7 \%$, maximum: $0.3 \%, P<0.01$, TRIM). The "Szatmár-Bereg" population declined by $86 \%(81 \%-90 \%)$ during the studied 20 years, whereas this value was not significant for the population of "Aggtelek" (mean: $-12 \%$, minimum: $-27 \%$, maximum 5\%).

The overall population trend of the Corncrake, based on these two populations, showed significant moderate decline (mean annual change: $-4.1 \%$ (minimum: $-4.9 \%$, maximum: $-3.4 \%, P<0.01$, TRIM). The population in these two regions declined by $55 \%(48 \%-61 \%)$ during the studied 20 years.

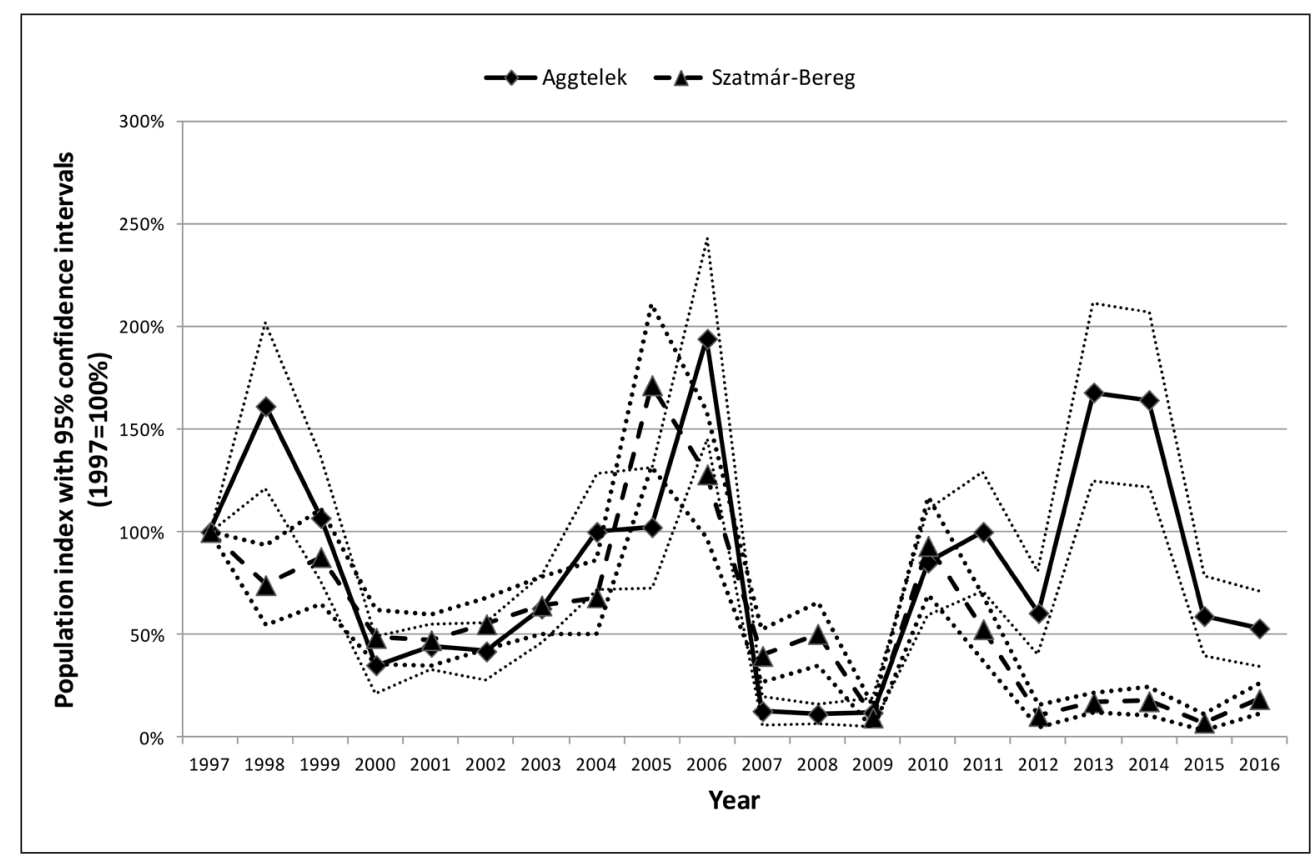

Figure 2. Population indices of the two studied breeding populations (Aggtelek, Szatmár-Bereg) during 1997-2016. Annual population index with 95\% confidence intervals, estimated with TRIM, are given for both populations

2. ábra A két vizsgált fészkelő populáció (Aggtelek, Szatmár-Bereg) populációs indexe azok 95\%-os konfidencia intervallumaival, TRIM által becsülve 1997-2016 között 


\section{Conservation status}

Forty-one percent of the breeding area of Corncrakes was covered by NATURA 2000 sites, including both Special Protection Areas (SPA) and Special Areas of Conservation (SAC). UTM quadrats overlapping with NATURA 2000 sites harboured 20\% of the breeding population. Eighteen percent of the breeding area was covered by nationally protected areas, including national parks, landscape protection areas and protected areas, and $13 \%$ of the population bred within UTM quadrats overlapping with protected areas. UTM quadrats overlapping with protected areas or NATURA 2000 sites together covered $42 \%$ of the distribution area and harboured $22 \%$ of the breeding population.

There are three agri-environment packages in the 2016-2020 programme with relevant prescriptions to Corncrakes (Rural Development Programme 2015-2020). The "Horizontal Grassland Package" is available for farmers of any grassland in the country. Although the Corncrake is not a target species of this package, the following optional measures are beneficial to the species: "bird-friendly mowing" and leaving $5-10 \%$ or $10-15 \%$ unmown as a refuge area during each cut. The "Lowland Bird Conservation Package" and the "Upland Bird Conservation Package" are available within certain HNVA, and Corncrake is a target species of these packages. According to the prescriptions of the "Lowland Bird Conservation Package", $50 \%$ of grasslands have to be mown or grazed after 1 July, "bird-friendly mowing" has to be applied, 10-15\% unmown area should be left during each cut, and at least 1 ha protective zone should be left unmown around the nests of protected birds in the case if they are discovered either by the farmer or national park directorate staff. The "Upland Bird Conservation Package" contains the same Corncrake-related prescriptions, except that 50\% of grasslands have to be mown or grazed after 31 July.

Forty percent of Corncrake breeding areas overlapped with HNVA with relevant packages for the species. While $23 \%$ of the breeding area was within eligible areas for the "Upland Bird Conservation Package", only 18\% was eligible for "Lowland Bird Conservation Package". Consequently, $67 \%$ of the total population bred within areas where any relevant agri-environment package is available, $47 \%$ within areas eligible for the "Upland Bird Conservation Package" and 20\% within eligible areas for "Lowland Bird Conservation Package".

\section{Current threats}

Nine major threatening factors to Corncrakes were identified by the experts of national park directorates (Table 1). By far the most common threat was mechanised mowing during the breeding season, occurring in $83 \%$ of breeding sites. Less widespread threats were grazing during the breeding season (13\%), encroachment of grassland by bushes and aridification of grassland habitats (10\%), which lead to inadequate cover for Corncrakes. The rest of the threats were restricted to only a few breeding sites, although they can be important there.

Mowing and grazing during the breeding season were also experienced as threats of high importance in the majority of breeding sites, whereas low importance is attributed to encroachment and medium importance to aridification in most breeding sites (Table 2). In addition, these four threats acted over a high proportion (19-50\%) of the area within breeding sites. 
It is also important to note that some of the less widespread threats may be of high importance if they affect large numbers of Corncrakes. Flooding, for example, is a serious problem in the Bodrogzug, the most important breeding site in Hungary. Similarly, man-made fires during the spring happen more and more frequently in the northern part of the breeding range, where a significant part of the population breeds.

\section{Applied conservation measures}

Based on the information provided by national park directorates, there were three main groups of conservation measures that are currently applied for Corncrakes. The most important one was the restriction of mowing during the breeding season, which has several variants (Table 2). This measure varied both in the area of the restriction and the date until when mowing was delayed. In most breeding sites (49\%), the restriction was often applied to the entire field in which calling males were detected, whereas the second most widespread measure was when restriction was applied often to more than 2 ha around the calling place (43\%). In most breeding sites (74\%), mowing was often delayed until 15 August, or until 1 August, which was applied much less frequently (23\%). In the most important breeding sites of Aggtelek, Bodrogzug and Szatmár-Bereg, mowing was delayed until 1 or 15 August in at least 2 hectares. In most breeding sites, several different measures were applied depending on protection status and ownership of grasslands. Very often it was impossible to apply a measure to every one of the known nesting places.

Table 1. Major threatening factors to Corncrakes in Hungary based on expert opinion of national park managers. Values of impact indicate the number of breeding sites from where the respective threat was reported as of high, medium or low importance. Values of extent indicate the mean percentage of area within breeding sites where the respective threat was detected

1. táblázat A harist veszélyeztető legfőbb tényezők a nemzeti park igazgatóságok szakembereinek véleménye alapján. A megadott értékek azoknak a költőterületeknek a számát mutatják, ahonnan az adott tényezőket jelentős, közepes vagy alacsony jelentőségűként jelezték, valamint annak a területnek az arányát, ahol a tényező kifejti a hatását

\begin{tabular}{|l|c|c|c|c|}
\hline \multirow{2}{*}{ Threat } & \multicolumn{4}{c|}{ Impact/extent } \\
& \multicolumn{4}{|c|}{ number of sites/percentage of area } \\
\cline { 2 - 5 } & high & medium & low & sum/mean \\
\hline mowing & $18 / 34$ & $6 / 42$ & $6 / 6$ & $30 / 30$ \\
\hline grazing & $6 / 30$ & $3 / 13$ & $4 / 8$ & $13 / 19$ \\
\hline encroachment & $2 / 35$ & $1 / 40$ & $9 / 16$ & $12 / 21$ \\
\hline aridification & $3 / 63$ & $6 / 51$ & $1 / 5$ & $10 / 50$ \\
\hline grassland conversion & 0 & $1 / 10$ & $2 / 2$ & $3 / 5$ \\
\hline spring burning & 0 & $3 / 6$ & $1 / 1$ & $4 / 5$ \\
\hline flooding & $1 / 100$ & $3 / 30$ & 0 & $4 / 48$ \\
\hline nest predation & $1 / 100$ & 0 & $2 / 18$ & $3 / 45$ \\
\hline intensification & 0 & 0 & $1 / 15$ & $1 / 15$ \\
\hline
\end{tabular}


Restricted grazing was applied in the territory of Kiskunság National Park, where grazing was the most typical management of grasslands. Since grazing is usually carried out on large areas at the same time, restrictions were also applied to entire fields or grazing districts. Grazing was most often delayed until 15 July, but sometimes also until 1 or 15 August.

Habitat reconstruction or improvement was conducted only in three breeding sites. In Aggtelek National Park, formerly important habitats were reconstructed by removing bushes and degraded reed beds from 40 hectares. In parallel, $4 \mathrm{~km}$ of fire lines were constructed to protect managed areas and maintain an appropriate vegetation structure for arriving Corncrakes in spring. In the Lower-Tisza Valley, an extra water supply was provided to grasslands, and arable fields were converted to grasslands to increase the area of potential habitats. In Örség National Park, large old fields and sown grasslands were improved via the creation of permanent refuge strips, increasing the variety of vegetation by variable mowing times and creating shrub edges within Corncrake habitats.

Table 2. Conservation measures applied to secure breeding success of Corncrakes in Hungary. The number of breeding sites where it is in use and the mean percentage of nesting sites affected by it within each site is shown for each measure

2. táblázat A haris sikeres költése érdekében alkalmazott természetvédelmi intézkedések Magyarországon. A táblázatban azoknak a költőhelyeknek a számát, illetve a költőhelyeken belül annak a területnek az arányát adjuk meg, ahol az adott intézkedést alkalmazzák

\begin{tabular}{|c|c|c|}
\hline Conservation measures & $\begin{array}{c}\text { Earliest date of mowing or } \\
\text { grazing }\end{array}$ & $\begin{array}{c}\text { Number of sites/percentage } \\
\text { of area }\end{array}$ \\
\hline \multicolumn{3}{|l|}{ Restricted mowing } \\
\hline entire field & 15 Aug & $13 / 49$ \\
\hline entire field & 1 Aug & $2 / 38$ \\
\hline entire field & 15 July & $4 / 33$ \\
\hline$>2$ ha & next year & $1 / 30$ \\
\hline$>2$ ha & 15 Aug & $11 / 61$ \\
\hline$>2$ ha & 1 Aug & $3 / 82$ \\
\hline 2 ha & 15 Aug & $4 / 85$ \\
\hline 2 ha & 1 Aug & $3 / 22$ \\
\hline 2 ha & 15 July & $1 / 10$ \\
\hline $1 \mathrm{ha}$ & 15 Aug & $6 / 33$ \\
\hline $1 \mathrm{ha}$ & 1 Aug & $2 / 40$ \\
\hline 1 ha & 20 July & $1 / 100$ \\
\hline \multicolumn{3}{|l|}{ Restricted grazing } \\
\hline entire field & 15 Aug & $1 / 50$ \\
\hline entire field & 1 Aug & $1 / 70$ \\
\hline entire field & 15 July & $2 / 20$ \\
\hline
\end{tabular}




\section{New insights from scientific literature}

Several works have been published on Corncrake ecology and conservation biology in the last 10 years. Here, we review those studies that have important implications for the practical conservation of the species.

\section{Monitoring}

The methodology of surveying Corncrakes is well established among experts (see papers published in the special issue of Vogelwelt 136), but minor differences may cause considerable discrepancies in population estimates. Budka and Kokociński (2015) compared three census methods by using them in parallel within $1 \times 1 \mathrm{~km}$ study plots: (i) territory mapping, when the location of each calling male is recorded by GPS, (ii) point-based censusing, when the distance and direction to calling males from five points (corners and centroid) was estimated in each study plot, and (iii) middle-point counting, when calling males were counted from the same five points within four distance categories $(0-50 \mathrm{~m}, 50-200$ $\mathrm{m}, 200-500 \mathrm{~m}, 500-1000 \mathrm{~m}$ ). Not surprisingly, territory mapping turned out to be the most accurate census technique. The middle-point counting method consistently underestimated population size, while the point-based census method overestimated population size when a small number of males were present within a study plot, but underestimated it when males were numerous.

Individual discrimination by male song was proposed as a potential way of population surveys (Kenyeres et al. 2000, Mikkelsen et al. 2013). Although it seemed to be an attractive and cost-effective method, a recent study, based on the recordings of 120 males, pointed out that it has severe limitations (Budka et al. 2015). The results of discrimination analyses, the statistical method used to assign song recordings to distinct individuals, are only reliable if the number of males is known prior to the analysis. This is, however, usually not the case when monitoring populations. It was shown that the method tends to underestimate populations if they consist of numerous individuals.

\section{Habitat requirements}

Understanding habitat requirements has always been a key issue in Corncrake conservation. Although the fundamentals of Corncrake's ecology were laid down long time ago (reviewed by Schäffer \& Koffijberg 2004, Koffijberg \& Schäffer 2006), several interesting findings have emerged in the last decade. A study in Scotland documented that Corncrakes were attracted in highest numbers by so-called cover areas that were specifically managed to provide vegetation tall enough throughout the breeding season (Corbett \& Hudson 2010). Fewer Corncrakes could be found in silage and hay fields and none in long-term set-asides without any management. These results are straightforward with regard to cover areas and managed fields based on previous studies (see references in Koffijberg \& Schäffer 2006), but are somewhat surprising in the case of set-asides. The authors of the study proposed that the sward of abandoned grasslands becomes too dense to allow the movements 
of Corncrakes and are therefore avoided by them (see also Tyler 1996, Green et al. 1997). In line with this latter argument, Grishchenko and Prins (2016) found in Russia that calling males were present in the highest density in old fields abandoned 5-15 years ago, whereas their density steeply declined after this period.

Several studies showed a shift in habitat preference of calling males between their first and second breeding attempt within the same season (Brambilla \& Pedrini 2011, Budka \& Osiejuk 2013). Males in the Italian Alps were more numerous at lower elevation sites $(<1000 \mathrm{~m})$ during the first half of the breeding season, and at higher elevation sites $(>1000 \mathrm{~m})$ during the second half (Brambilla \& Pedrini 2011). The shift is most likely explained by changes in habitat suitability, i.e., earlier-mown lower sites become unsuitable, whereas a slower-growing vegetation in higher meadows reach the required height by the middle of the breeding season (see also Delov \& Iankov 1997). Males in Eastern Poland preferred abandoned meadows at the beginning of the breeding season, and the proximity of bushes increased the chance of site occupancy (Budka \& Osiejuk 2013). In the second part of the breeding season, however, extensively mown meadows were the most common habitat in the territory of male Corncrakes. This phenomenon is also attributed to the fact that vegetation of mown meadows provides enough cover by the second part of the season.

The broader landscape also matters for Corncrakes as shown by a recent study in Transylvania, Romania (Dorresteijn et al. 2015). Here, breeding Corncrakes preferentially occupied areas where landscape heterogeneity was high at the 100 ha scale. A simulation model indicated that a loss of only $35 \%$ of this landscape diversity may result in a $66 \%$ decrease in the availability of suitable habitats. An observation in the Italian Alps also supported the predictions of this model, because the Corncrake population declined in parallel with the introduction of agricultural subsidies that promoted mowing in all fields within the same period. This, therefore, reduced the diversity of vegetation structure available in the area (Brambilla \& Pedrini 2013).

\section{Dispersion}

It is well known that male Corncrakes may travel large distances within a breeding season, which has important implications for conservation (summarised by Koffijberg et al. 2016). However, it is still unclear how frequent these dispersal events are and what factors drive males to leave their territory. The main reason for the lack of data on dispersal is the difficulty of catching and ringing Corncrakes in large enough quantities for traditional mark-recapture/recover studies. Although radio tracking offered an attractive alternative (e.g., Hoffmann 1997), there are some uncertainties in localising individuals beyond larger distances, since the area to be searched increases steeply with dispersal distance. Two alternative methods have recently been used to follow the movements of Corncrakes: satellite tracking and individual identification based on call discrimination.

Eight male Corncrakes were attached with satellite transmitters along the Czech-German border in 2012-2014. Satellite tracking allowed them to be followed throughout the breeding season and even during migration (Peške et al. 2015). All but one of these males remained in the same field until the autumn migration. One male left the breeding area after 
the field in which it was calling had been mowed, and after several stopovers it ended up in Hungary, $580 \mathrm{~km}$ away from its origin.

Song recognition may be a promising way of tracking the movement of individual males both within and between populations, as it requires much less resources than radio tracking, ringing or satellite tracking (Peake et al. 1998, Kenyeres et al. 2000, Peake \& McGregor 2001). Detailed analyses of recordings, however, revealed that there is a relatively high likelihood of chance similarities between the songs of distinct males, especially in large populations (Mikkelsen et al. 2013, Budka et al. 2015). Therefore, results of song analyses should be used with caution to study dispersal behaviour in Corncrakes.

Another important aspect of dispersal is to understand its driving factors. Much evidence revealed that males were more likely to leave their breeding sites if mowing happened near their calling places (Van den Bergh 1991, Hoffmann 1997, Mikkelsen et al. 2013, Peške et al. 2015). Consequently, disturbance and habitat loss might be two of the main reasons for long-distance dispersal in this species.

\section{Conservation management}

In spite of the long history of Corncrake conservation, there is a shortage of well-documented management programmes, especially on the effectiveness of different conservation measures. One of the main reasons for the scarcity of evidence is the obscure life of this species, which makes the estimation of its breeding success almost impossible (Schäffer \& Koffijberg 2004). Fortunately, the International Corncrake Conference in Pilsen, 2015, provided an excellent opportunity to share experiences from practical conservation programmes (BirdLife International Corncrake Conservation Team 2016).

One of the most thoroughly documented conservation programmes was conducted in Scotland, and resulted in the tripling of the Corncrake population in 30 years (Beaumont \& England 2016). The basis of the programme was the establishment of so-called cover areas within protected areas, which provided vegetation tall enough throughout the breeding season. These were fields of $0.1-4$ ha near hay or silage that were mown or grazed once a year after 1 August. Some of these cover areas were created artificially by fertilising the soil and then sowing or planting one or a combination of the following plants: cow parsley (Anthriscus sylvestris), stinging nettle (Urtica dioica) and yellow iris (Iris pseudochorus). The protected areas where these measures were applied supported 10-15\% of Corncrake population in the UK. Outside the protected areas, agri-environment schemes were introduced. Farmers enrolled into these programmes were subsidised to mow their meadows after $1 \mathrm{Au}-$ gust or 15 August or 1 September and to create special cover areas. Since 1998, the majority of the UK Corncrake population has been covered by these agri-environment schemes.

After the collapse of the Corncrake population in Switzerland by 1970, a conservation programme was started by SVS/BirdLife Switzerland in 1996. The programme was based on the determination of exact calling places of males and then delayed mowing after $15 \mathrm{Au}-$ gust on 1 ha around the calling place (Inderwildi 2016). After launching the programme, the breeding population increased considerably and $48 \%$ of all calling males were recorded from grasslands with conservation measures. 
Refuge stripes have become an important instrument in the management of Corncrake habitats and have proven to be efficient in reducing mortality during mowing operations (Tyler et al. 1998). A recent study in Germany added further details to this measure by the radio tracking of adult and juvenile Corncrakes (Arbeiter et al. 2015). The results of this study suggested that refuge stripes should be at least $10 \mathrm{~m}$ wide, since the majority of Corncrakes $(25-66 \%)$ stayed in the unmown area until its width went below this threshold. Refuge areas could provide not only temporal cover but also suitable habitat until the fledging of young birds, provided their width was between 10-30 metres.

\section{Conclusions and recommendations for future conservation efforts}

Based on the analyses of $2.5 \times 2.5 \mathrm{~km}$ UTM grid distribution data, we found that $22 \%$ of the Hungarian Corncrake population breeds within either nationally protected areas or NATURA 2000 sites, where legal means are available to secure their breeding success. Even more, $67 \%$ breeds in HNVA, where relevant management prescriptions are applied to grasslands. These results should be interpreted by caution, because they do not take into account the exact location of breeding sites, so the number of pairs nesting in protected, NATURA 2000 or HNVA could be higher or lower. Our calculations are a rather rough estimation of the overlap between these areas and the distribution of Corncrakes.

In spite of the relatively good coverage of the population by areas with a good potential for Corncrake conservation, the Corncrake population seems to be steeply declining. One potential explanation for this contradiction might be that the decline is due the decline of subpopulations outside of protected areas. This is, however, unlikely, since the decline was detected exactly in the protected area of Szatmár-Bereg. Other reasons for the decline may be that either the conservation measures are not always applied, or the measures applied are not adequate. The first scenario may happen in HNVA, where farmers can participate in the agri-environment scheme on a voluntary basis, and therefore only a smaller portion of the eligible areas may be really managed for Corncrakes. In addition, prescriptions in the "Lowland Bird Conservation Package" are not entirely suitable for the species, since mowing is only delayed until 1 July. We know, however, that mowing before 1 August may still cause breeding failure, especially in the second broods (Green et al. 1997, Green 2010). It should also be considered that the Hungarian population is not independent from other populations, and influxes from eastern breeding areas may cause large fluctuations in Hungary (Fourcade et al. 2016, Koffijberg et al. 2016).

Conservation measures applied by national park managers both within and outside protected areas seem to address major threatening factors. In most breeding sites, including the most important ones in North-Eastern Hungary, mowing is delayed until 1 or 15 August on at least 2 hectares around calling places of males. This is in line with the most recent recommendations of the BirdLife International Corncrake Conservation Team (2016). In other cases, mowing or grazing is only delayed until 15 July and only 1 ha is left unmown around calling places of males, which both are insufficient to secure successful breeding (Green et al. 1997). Any conservation measure is, however, applied to only to $48 \%$ of all nesting pairs on average 
within breeding sites, which may further reduce their overall effectiveness (Table 2). To enhance positive effects of conservation measures, two main steps could be recommended. First, more efforts should be allocated to surveys to discover most of the calling males and thereby determine nesting places, so that a larger fraction of the population can be subjected to measures. Second, mowing or grazing on occupied grasslands should be delayed until 15 August by when both the first and second broods reach independence (Green et al. 1997, BirdLife International Corncrake Conservation Team 2016). If the entire field cannot be left unmown, at least 2 ha around the calling sites should be left unmown or excluded from grazing.

Well-documented conservation programmes can also help us to refine our conservation measures and make them more efficient. From the results of the Scottish conservation programme and landscape-scale studies (Dorrestijn et al. 2015, Beaumont \& England 2016), we conclude that a network of high-quality cover areas should be maintained at least in core breeding areas. These grasslands should be managed primarily for Corncrakes, independent of the current presence or absence of breeding pairs. They should be mown no more than once a year and not earlier than 15 August. Cover areas may promote landscape-scale habitat heterogeneity and thereby keep the area attractive for Corncrakes (Brambilla \& Pedrini 2013, Dorrestijn et al. 2015). Furthermore, they may provide an opportunity to produce a second clutch by some individuals in the population, which is an important condition for a stable population (Green et al. 1997, Green 2010).

Besides high-quality habitats, agri-environment measures can also be important means of Corncrake-friendly grassland management outside protected areas (Boldogh et al. 2016b). Among the currently applied measures, inside-outward mowing, refuge stripes and delayed mowing until 1-15 August are well established by previous studies (see Koffijberg \& Schäffer 2006, BirdLife International Corncrake Conservation Team 2016). Thanks to a recent study, we also learned that refuge stripes should be at least 10-30 metres wide to provide suitable cover and habitat for young Corncrakes until fledging (Arbeiter et al. 2015). It would be also important to involve more farmers in agri-environment programmes at least in the most important breeding areas, and thereby increase the proportion of breeding pairs affected by conservation measures. The spatial extension of High Nature Value Areas with Corncrake-friendly prescriptions would also be desirable.

There are important threats, such as aridification or flooding, which are much more difficult to tackle. Unfortunately, these problems affect the most important breeding populations in North-East Hungary, and could not yet be addressed by conservation managers. The severe decline in the "Szatmár-Bereg" population could also be attributed to warmer weather during the breeding season (Bartholy et al. 2014), which could have reduced the number and size of the suitable breeding habitats for Corncrakes (Wettstein et al. 2001). Although water supply to drying Corncrake habitats was provided in the Kiskunság National Park, more reconstruction projects would be necessary to halt the deterioration of important habitats.

Monitoring the effect of conservation measures is also necessary to be able to develop them further. For monitoring populations, territory mapping is recommended, which provides the most accurate estimates from the available methods (Budka \& Kokociński 2015). However, surveys should be extended to larger areas, because Corncrakes may shift between habitats over the breeding season (Brambilla \& Pedrini 2011, Budka \& Osiejuk 2013). 
As grasslands are habitats for a number of other plant and animal species of conservation relevance, the influence of Corncrake-friendly management on other species should be considered as well. A previous study revealed that both butterfly and bird species richness was higher in those grasslands that were occupied by Corncrakes than in control sites without Corncrakes (Wettstein \& Szép 2003). The density of Corn Bunting (Emberiza calandra) and Tree Pipit (Anthus trivialis) was also higher in Corncrake habitats. Other species, e.g. Skylark (Alauda arvensis) and Yellow Wagtail (Motacilla flava), however, prefer shorter swards than Corncrake. A recent study also found that the highest plant diversity of mesic hay meadows can be achieved by mowing them twice a year (Szépligeti et al. 2016), which is unsuitable for Corncrakes. Therefore, conservation management of grasslands should choose its targets for each field and treat them accordingly.

\section{Acknowledgements}

We would like to thank colleagues at the Aggtelek, Balaton Uplands, Bükk, Duna-Ipoly, Duna-Dráva, Fertő-Hanság, Hortobágy, Kiskunság, Körös-Maros and Örség National Park Directorates for their help during the field surveys and for allowing us to use their data. Special thanks to Ádám Szabó, Zsolt Szegedi, Roland Farkas, Attila Huber, László Lontay, Tamás Visnyovszky, Csaba Megyer, Ádám Pongrácz, Zsófia Mocskonyi, Dénes Laczik, Sándor Tatai, Miklós Lóránt, Péter Bánfi and Ádám Faragó for coordinating the completion of our questionnaire by their colleagues in their respective national park directorates. We are also grateful to the Monitoring Centre of Birdlife Hungary (MME) for contributing data.

\section{References}

Arbeiter, S., Helmecke, A. \& Bellebaum, J. 2015. 10 m unmown - Do Corncrakes benefit from refuge stripes? Conference poster, International Corncrake Conference, Pilsen

Bartholy, J., Pongrácz, R. \& Pieczka, I. 2014. How the climate will change in this century? - Hungarian Geographical Bulletin 63: 55-67. DOI: 10.15201/hungeobull.63.1.5

Beaumont, D. J. \& England, B. J. 2016. The Corncrake population in Scotland from 1993 to 2015 with an overview of conservation measures taken during this period. - Vogelwelt 136: 153-162.

BirdLife International 2015. European Red List of Birds. - Office for Official Publications of the European Communities

BirdLife International Corncrake Conservation Team 2016. Fifth meeting of the Corncrake Conservation Team 2015. - Vogelwelt 136: 71-72.

Boldogh, S. \& Szentgyörgyi, P. 2003. A haris (Crex crex L. 1758) állományának vizsgálata az Aggteleki Nemzeti Park Igazgatóság illetékességi területén 1997-2002 között [Research on Corncrake (Crex crex L. 1758) in the administrative area of Aggtelek N. P. (N. Hungary) between 1997 and 2002]. - ANP Füzetek 2: 77-96. (in Hungarian)

Boldogh, S. A., Visnyovszky, T., Szegedi, Zs., Habarics, B., Horváth, R., Krajnyák, C. \& Lengyel, S. 2016. Where can flood refugees go? Re-distribution of Corncrakes (Crex crex) due to floods and its consequences on grassland conservation in North-Eastern Hungary. - Ornis Hungarica 2016(2): 18-31. DOI: 10.1515/orhu-2016-0012

Boldogh, S., Szegedi, Z., Szentgyörgyi, P. \& Petrovics, Z. 2009. Distribution, population size and conservation of Corncrake Crex crex in North-east Hungary, 1997-2006. - Vogelwelt 130: 153-158.

Boldogh, S., Szentirmai, I., Nagy, K. \& Habarics, B. 2016b Distribution, population trends and conservation status of the Corncrake (Crex crex) in Hungary, 2007-2015. - Vogelwelt 136: 121-126.

Brambilla, M. \& Pedrini, P. 2011. Intra-seasonal changes in local pattern of Corncrake Crex crex occurrence 
require adaptive conservation strategies in Alpine meadows. - Bird Conservation International 21: 388-393. DOI: $10.1017 / \mathrm{S} 0959270910000572$

Brambilla, M. \& Pedrini, P. 2013. The introduction of subsidies for grassland conservation in the Italian Alps coincided with population decline in a threatened grassland species, the Corncrake Crex crex. - Bird Study 60: 404-408. DOI: 10.1080/00063657.2013.811464

Budka, M. \& Kokociński, P. 2015. The efficiency of territory mapping, point-based censusing, and point-counting methods in censusing and monitoring a bird species with long-range acoustic communication - the Corncrake Crex crex. - Bird Study 62: 153-160. DOI: 10.1080/00063657.2015.1011078

Budka, M. \& Osiejuk, T. S. 2013. Habitat preferences of Corncrake (Crex crex) males in agricultural meadows. Agriculture Ecosystems and Environment 171: 33-38. DOI: 10.1016/j.agee.2013.03.007

Budka, M., Wojas, L. \& Osiejuk, T. S. 2015. Is it possible to acoustically identify individuals within a population? - Journal of Ornithology 156: 481-488. DOI: 10.1007/s10336-014-1149-2

Chernel, I. 1899. Magyarország madarai különös tekintettel gazdasági jelentőségökre. Második könyv. Tüzetes rész [Birds of Hungary with a special focus on their economic significance. Detailed part]. - Magyar Ornithologiai Központ, Budapest, pp. 389-391. (in Hungarian)

Corbett, P. E. \& Hudson, M. D. 2010. Management of cover areas may increase numbers of breeding Corncrakes Crex crex. - Bird Study 57: 553-559. DOI: 10.1080/00063657.2010.489601

Delov, V. \& Iankov, P. 1999. National survey of the Corncrake Crex crex in Bulgaria in 1995. - Vogelwelt 118: 239-241.

Dorresteijn, I., Teixeira, L., von Wehrden, H., Loos, J., Hanspach, J., Stein, J. A. R. \& Fischer, J. 2015. Impact of land cover homogenization on the Corncrake (Crex crex) in traditional farmland. - Landscape Ecology 30: 1483-1495. DOI: $10.1007 / \mathrm{s} 10980-015-0203-7$

Fourcade, Y., Engler, J. O., Besnard, A. G., Rödder, D. \& Secondi, J. 2013. Confronting expert based and modelled distributions for species with uncertain conservation status: a case study from the Corncrake (Crex crex). - Biological Conservation 167: 161-171. DOI: 10.1016/j.biocon.2013.08.009

Fourcade, Y., Richardson, D. S., Keišs, O., Budka, M., Green, R. E., Fokin, S. \& Jean Secondi, J. 2016. Corncrake conservation genetics at a European scale: The impact of biogeographical and anthropological processes. Biological Conservation 198: 210-219. DOI: 10.1016/j.biocon.2016.04.018

Green, R. E. 2010. Timing of breeding, primary moult and duration of maternal care of chicks by adult female Corncrakes Crex crex. - Ibis 152: 826-829. DOI: 10.1111/j.1474-919x.2010.01042.x

Green, R. E., Rocamora, G. \& Schäffer, N. 1997. Populations, ecology and threats to the Corncrake Crex crex in Europe. - Vogelwelt 118: 117-134.

Gregory, R. D., Vořišek, P., Noble, D. G., van Strien, A., Klvaňová, A., Eaton, M., Meyling, A. W. G., Joys, A., Foppen, R. P. B. \& Burfield, I. J. 2008. The generation and use of bird population indicators in Europe. - Bird Conservation International 18: S223-S244. DOI: 10.1017/s0959270908000312

Grishchenko, M. \& Prins, H. H. T. 2016. Abandoned field succession in Russia and its potential effect on Corncrake Crex crex habitats. - Vogelwelt 136: 163-174.

Hoffmann, M. 1997. Rufplatzwahl des Wachtelkönigs Crex crex und Verbleib von Individuen nach Verlust des Bruthabitats in Nordostpolen [Choice of calling place by Corncrakes Crex crex and site fidelity of individuals after the loss of their breeding habitat in North-East Poland]. - MSc Thesis, University of Freiburg, Freiburg (in German)

Horváth, R. 1998. Haris (Crex crex) [Corncrake]. - In: Haraszthy, L. (ed.) Magyarország madarai [Birds of Hungary]. - Mezőgazda Kiadó, Budapest (in Hungarian)

Inderwildi, E. 2016. Population trend, time of arrival and altitudinal distribution of Corncrake Crex crex in Switzerland - the results of 20 years of conservation. - Vogelwelt 136: 107-112.

Kenyeres, A., Wetstein, W. \& Szép, T. 2000. Haris egyedek felismerése hangelemzés alapján [Individual recognition of Corncraces (Crex crex) by sound analysis]. - Ornis Hungarica 10: 65-70. (in Hungarian with English Summary)

Koffijberg, K. \& Schäffer, N. (compilers) 2006. Single Species Action Plan for the Conservation of the Corncrake Crex crex. - CMS Technical Series No. 14. \& AEWA Technical Series No. 9. CMS, AEWA, European, Union, Bonn, Germany

Koffijberg, K., Hallman, C., Keišs, O. \& Schäffer, N. 2016. Recent population status and trends of Corncrakes Crex crex in Europe. - Vogelwelt 136: 75-87.

McCullagh, P. \& Nelder, J. A. 1989. Generalized linear models, $2^{\text {nd }}$ ed. - Chapman \& Hall, London

Mikkelsen, G., Dale, S., Holtskog, T., Budka, M. \& Osiejuk, T. S. 2013. Can individually characteristic calls be used to identify long-distance movements of Corncrakes Crex crex? - Journal of Ornithology 154: 751-760. DOI: 10.1007/s10336-013-0939-2 
MME BirdLife Hungary 2016. - Magyarország madarai: Haris [Birds of Hungary: Corncrake]. http://www.mme. hu/magyarorszagmadarai/madaradatbazis-crecre (last access: 14.10.2016) (in Hungarian)

Pannekoek, J. \& van Strien, A. J. 2001. TRIM 3 Manual. Trends and Indices for Monitoring Data. - Research Paper no. 0102.

Peake, T. M. \& McGregor, P. K. 2001. Corncrake Crex crex census estimates: a conservation application of vocal individuality. - Animal Biodiversity Conservation 24: 81-90.

Peake, T. M., McGregor, P. K., Smith, K. W., Tyler, G., Gilbert, G. \& Green, R. E. 1998. Individuality in Corncrake Crex crex vocalization. - Ibis 140: 120-127. DOI: 10.1111/j.1474-919x.1998.tb04548.x

Peške, L., Vlček, J., Schmidberger, M., Peš, P. \& Pešová, J. 2015. Satellite tracking of Corncrakes Crex crex. Conference poster, International Corncrake Conference, Pilsen

Schäffer, N. \& Koffijberg, K. 2004. Crex crex Corncrake. - Birds of Western Palaearctic update Vol. 6. - Oxford University Press, London, pp. 55-76.

Schäffer, N. \& Mammen, U. 2003. International Corncrake monitoring. - Ornis Hungarica 12-13: 129-133.

Szép, T. \& Waliczky, Z. 1993. Ritka és telepesen fészkelő madarak monitoring programja [Monitoring of rare and colonial breeding birds]. - Magyar Madártani és Természetvédelmi Egyesület (BirdLife Hungary), Budapest (in Hungarian)

Szép, T. 1991. The present and historical situation of the Corncrake in Hungary. - Vogelwelt 112: 45-48.

Szép, T., Nagy, K., Nagy, Zs. \& Halmos, G. 2012. Population trends of common breeding and wintering birds in Hungary, decline of long-distance migrant and farmland birds during 1999-2012. - Ornis Hungarica 20(2): 13-63. DOI: 10.2478/orhu-2013-0007

Szépligeti, M., Körösi, Á., Szentirmai, I., Házi, J., Bartha, D. \& Bartha, S. 2016. Evaluating alternative mowing regimes for conservation management of Central European mesic hay meadows: A field experiment. - Plant Biosystems - An International Journal Dealing with all Aspects of Plant Biology DOI: $10.1080 / 11263504.2016 .1255268$

Tyler, G. 1996. The ecology of the Corncrake: with special reference to the effect of mowing on breeding production. - PhD Thesis, University College Cork

Tyler, G. A., Green, R. E. \& Casey, C. 1998. Survival and behaviour of Corncrake Crex crex chicks during the mowing of agricultural grassland. - Bird Study 45: 35-50. DOI: 10.1080/00063659809461076

van Den Bergh, L. M. J. 1991. Status, distribution and research on Corncrakes in the Netherlands. - Vogelwelt 112: 78-82.

van Strien, A. J., Pannekoek, J. \& Gibbons, D. W. 2001. Indexing European bird population trends using results of national monitoring schemes: a trial of a new method. - Bird Study 48: 200-213. DOI: $10.1080 / 00063650109461219$

Wettstein, W. \& Szép, T. 2003. Status of the Corncrake Crex crex as an indicator of biodiversity in eastern Hungary. - Ornis Hungarica 12-13: 143-149.

Wettstein, W. 1999. Conservation status of the Corncrake (Crex crex) in Szatmár-Bereg (Eastern Hungary). - Proceedings from the Second International Wildlife Management Congress 1999. Gödöllö, University of Agricultural Sciences, Hungary \& The Wildlife Society, USA, p. 107.

Wettstein, W., Szép, T. \& Kéry, M. 2001. Habitat selection of Corncrakes (Crex crex L.) in Szatmár-Bereg (Hungary) and implications for further monitoring. - Ornis Hungarica 11: 9-18.

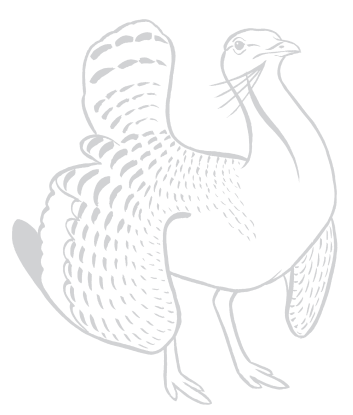

